\title{
ВЗАЕМОДІЯ ГРОМАДСЬКОСТІ ТА ДЕРЖАВИ У СФЕРІ ПУБЛІЧНОГО АДМІНІСТРУВАННЯ В УКРАЇНІ
}

Левченко Д. С.

Устаттірозкрито особливості взаємодії громадськості та держави в сфері публічного адміністрування в Україні. Встановлено, що сучасна взаємодія громадськості та держави в сфері публічного адміністрування в Україні повинна будуватися на засадах деліберативної демократії, тобто через компетентне обговорення громадськістю діяльності публічної адміністрації та комплексну співпрацю громадськості та влади, в якій саме влада є зацікавленим суб'єктом співпраці з громадськістю з метою росту компетенції інститутів громадянського суспільства та ефективного виконання поставлених перед державою завдань і функцій. Визначено найпоширеніші форми взаємодії громадськості та держави в сфері публічного адміністрування в Україні.

Ключові слова: взаємодія, громадськість, інклюзивність, незалежність, органи влади, принципи, прозорість, публічне адміністрування.

В статье раскрыты особенности взаимодействия общественности и государства в сфере публичного администрирования в Украине. Установлено, что современное взаимодействие общественности и государства в сфере публичного администрирования в Украине должно строиться на принципах делиберативной демократии, то есть через компетентное обсуждение общественностью деятельности публичной администрации и комплексное сотрудничество общественности и власти, в какой именно власть является заинтересованным субъектом сотрудничества с общественностью с целью роста компетенции институтов гражданского общества и эффективного выполнения поставленных перед государством задач и функций. Oпределены самые распространенные формы взаимодействия общественности и государства в сфере публичного администрирования в Украине.

Ключевые слова: взаимодействие, общественность, инклюзивность, независимость, органы власти, принципы, прозрачность, публичное администрирование.

The article describes the peculiarities of interaction between the public and the state in the sphere of public administration in Ukraine, which tries to be built on the basis of international and European principles of participation of civil society institutions in the field of activity of the authorities. It is established that the modern interaction between the public and the state in the sphere of public administration in Ukraine should be based on the principles of deliberative democracy, that is through competent public discussion of the activities of the public administration and complex cooperation of the public and the authorities, in which the authorities are interested in the subject increasing the competence of civil society institutions and the effective implementation of the tasks and functions of the state.

The most widespread forms of interaction between the public and the state in the sphere of public administration in Ukraine are determined: implementation of normative-making activity, implementation of public powers delegated by the state, public control and monitoring, citizen-assisted performance measurement and public-law activities, public activity in the field of law enforcement, implementation of administrative and service actions of the state, etc.
The public is involved in various spheres of public administration: norm-making (including, in the sphere of issuing regulations and by-laws by the subjects of public administration as a form of their administrative activity); legal implementation (when the public independently participates in public administration; when the state authorizes them to perform certain tasks and functions to implement the rules of law in society; when the state and the public cooperate in the field of enforcement); law enforcement (public control as a way of influence, joint partnership actions of the public and law enforcement agencies, independent public participation in law enforcement activities); in the field of judicial administration (functioning of the Public Council of Integrity, Public Council of International Experts, cooperation between judicial authorities and public associations on the independence of judges, evaluation of the work of a judge by public associations, etc.).

Key words: interaction, public, inclusivity, independence, authorities, principles, transparency, public administration.

Постановка проблеми та іï актуальність. Для реального задоволення інтересів суспільства держава повинна «прислухатися» до інститутів громадянського суспільства через різні форми. Така взаємодія громадськості та держави дозволить не лише якісно виконувати державні завдання та функції, а й розвинути правову, політичну та соціальну обізнаність інститутів громадянського суспільства, виховати досвідчене суспільство, яке буде гармонійно взаємодіяти з державною заради загального розвитку.

Найпоширенішою співпрацею громадськості та держави є взаємодія у сфері публічного адміністрування, яка охоплює безліч правових площин. В Україні існують проблеми в цій сфері, що підкреслює Національна стратегія сприяння розвитку громадянського суспільства в Україні на 2016-2020 роки. Вона вказує, що у державі існують такі проблеми розвитку громадянського суспільства: відсутній ефективний громадський контроль за діяльністю органів державної влади, органів місцевого самоврядування; недостатньою $€$ практика залучення громадськості до формування та реалізації державної політики і вирішення питань місцевого значення; благодійники не мають ефективних стимулів з боку держави, зокрема податкових, обтяжені бюрократичними процедурами, відсутній дієвий механізм захисту від шахрайства та інших зловживань у сфері благодійництва; більшість організацій громадянського суспільства не має доступу до державної фінансової підтримки через її обмежений обсяг, незастосування прозорих конкурсних процедур і надання необґрунтованих переваг окремим видам організацій громадянського суспільства; потенціал організацій громадянського суспільства не повністю використовується органами влади; недостатніми є стимули щодо 
здійснення організаціями громадянського суспільства підприємницької діяльності, спрямованої на вирішення соціальних проблем (соціальне підприємництво); відсутня єдина державна інформаційно-просвітницька політика у сфері сприяння розвитку громадянського суспільства [7]. Загалом відсталість у розвитку громадянського суспільства в Україні спричинена низкою факторів, які необхідно якнайшвидше вирішити шляхом забезпечення ефективної взаємодії громадськості та держави в сфері публічного адміністрування.

Аналіз останніх досліджень і публікацій. Взаємодію між громадськістю та публічною адміністрацією у своїх працях досліджували Н. Берлач, А. Буханевич, В. Галунько, О. Джафарова, К. Дубич, О. Іващенко, Н. Калинець, Л. Кисіль, О. Костюшко, С. Коханчук, В. Курило, Я. Лазур, М. Лошицький, О. Онуфрієнко, С. Параниця, А. Половченя, А. Приймак, $Є$. Соболь, С. ТимофєєВ, І. Тищенкова, Ю. Ткаченко, О. Тронько, В. Цимбалюк та інші. Після революційних подій українське суспільство ще активніше почало вимагати від держави удосконалення механізму участі громадськості в публічному адмініструванні, тому сучасні наукові дослідження у цій площині $є$ надзвичайно актуальною проблематикою.

Мета статті полягає в тому, щоб на основі положень чинного національного та міжнародного законодавства, позицій вчених-юристів та аналізу діяльності громадськості та практики функціонування суб'єктів публічної адміністрації визначити та охарактеризувати взаємодію громадськості та держави в сфері публічного адміністрування в Україні.

Виклад основного матеріалу. В Україні прогресує концепція деліберативної демократії, у якій певним чином вирішується проблема народного суверенітету, а також проблеми ефективної комунікації, легітимності та підконтрольності державного апарату громадянам держави, які постають в особливій формі [5, с. 18-23]. Ця концепція відрізняється як від класичного адміністрування, за яким єдиним джерелом політичних рішень $€$ політичне керівництво, так і від нового публічного менеджменту з його акцентом на торговельній угоді, де кожен учасник намагається максимізувати свій прибуток. Вона здатна більш ефективно задовольняти суспільні потреби та виробляти соціально значущі рішення. Концепція характеризується використанням політичної, економічної, адміністративної влади для управління державними ресурсами і справами. Вона включає механізми, процеси та структури, за допомогою яких органи влади, громадяни та соціальні групи координують свої інтереси, використовують права та виконують обов'язки, а також виступають посередниками у вирішенні проблемних питань розвитку суспільства [2, с. 101-107; 4, с. 2-3; 3, с. 140].

Деліберативний дискурс сприяє зміцненню громадянського суспільства, який $є$ своєрідним тригером політичної модернізації. Консолідована громада краще усвідомлює власні інтереси, належним чином формулює спільні вимоги та доносить їх до держави та інших політичних інститутів. Деліберація пропонує нове тлумачення раціональності, легітимності, публічності, громадськості. Методологію деліберативного обговорення О. Дем'яненко визначив як семантичний процесинг, який дозволяє всім учасникам заходу краще зрозуміти суть проблеми та значення різних способів їі розв'я- зання не без допомоги експертів, які можуть висловити свою кваліфіковану думку, однак слід уникати домінування спільноти фахівців. Така методологія відкриває шлях якісному росту громадянської компетентності та відповідальності водночас. Деліберативний дискурс стимулює фасилітацію перцепції публічних викликів і фідбеків [2, с. 101-107].

В. Медведська вважає, що деліберативні механізми можна класифікувати так: 1) механізми деліберації у формальній політичній сфері: парламентські дебати; деліберація в органах місцевого самоврядування; громадські ради; відкриті засідання державних органів; консультації з громадськістю (опитування громадської думки, електронні консультації, громадські слухання); 2) механізми деліберації у неформальній політичній сфері: неформальні з можливим переходом у формальну політичну сферу (громадська експертиза, громадський контроль); суто неформальні (громадське обговорення в 3МІ, громадські форуми, адвокасі-кампаніiі) [5, с. 18-23].

Сучасне публічне адміністрування в Україні повинно бути побудовано на засадах деліберативної демократії, тобто, здійснення публічного адміністрування через компетентне обговорення громадськістю діяльності публічної адміністрації та комплексну співпрацю громадськості та влади, в якій саме влада $є$ зацікавленим суб'єктом співпраці 3 громадськістю $з$ метою росту компетенції інститутів громадянського суспільства та ефективного виконання поставлених перед державою завдань і функцій.

Взаємодія громадськості та держави в сфері публічного адміністрування в Україні $\epsilon$ досить специфічною, однак при цьому, як переконана Н. Мельник, громадянське суспільство і держава не можуть існувати одна без одної, оскільки держава здійснює вплив на суспільство, гарантуючи та закріплюючи законодавчу, виконавчу і судову гілки влади та забезпечуючи права людини та народу. Громадянське суспільство відстоює матеріальну та духовну незалежність людини від держави, домагається правової гарантії такої незалежності, захищає приватні та суспільні інтереси людей і активно сприяє процесам демократизації держави. 3 іншого громадянське суспільство залежить від держави і не може набути розвинених форм в умовах політичного насильства та тиранії. Тому взаємодія інститутів громадянського суспільства з органами державної влади $\epsilon$ основною вимогою існування демократичної та правової держави [6, с. 25].

У процесі оптимізації взаємодії з інститутами громадянського суспільства О. Чепік-Трегубенко вказує, що істотне значення мають такі форми діяльності органів публічної влади: 1) формування нормативно-правової бази, реалізація якої дозволяє забезпечити правову захищеність громадян, їх соціальних і громадських об'єднань; 2) здійснення заходів зміцнення довіри між органами публічної влади та інститутами громадянського суспільства: інформаційна відкритість публічної влади; вчасне інформування громадськості про політичні рішення; доступність і підзвітність органів влади тощо; 3) забезпечення активної участі громадян у державному управлінні. Право на участь в управлінні державними справами та його реалізація має вирішальне значення для розвитку громадянського суспільства. Сьогодні існує необхідність у створенні інституцій- 
них і правових механізмів залучення інститутів громадянського суспільства до вироблення та реалізації публічної політики в Україні. Становлення ефективної вітчизняної моделі участі громадськості в управлінні державними справами сприяє формуванню дієвого громадянського суспільства на основі відповідних європейських стандартів; 4) сприяння процесу підвищення політичної культури населення, об'єднання населення навколо єдиних національних цінностей. Політичну культуру громадянського суспільства необхідно розвивати як одну з головних умов соціально-політичної стабільності. Залучення громадян до процесу прийняття рішень сприятиме формуванню демократичної політичної культури в Україні [9, с. 120-126].

Г. Шаульська виділяє такі сучасні вертикальні і горизонтальні механізми співпраці органів влади з інститутами громадянського суспільства: механізм реалізації виборів; створення та діяльність консультативно-дорадчих органів при органах виконавчої влади та органах місцевого самоврядування; громадські слухання, публічні обговорення, конференції, семінари, «круглі столи»; підписання угод та договорів про співпрацю на міжрегіональному рівні; механізм фінансової підтримки проектів, програм, заходів об'єднань і організацій громадян; моніторинг громадської думки та проведення різноманітних соціологічних досліджень; просвітницький механізм формування громадянських компетентностей; механізм обміну інформацією [10, с. 189].

Громадськість взаємодіє з державою в сфері публічного адміністрування через такі найпоширеніші форми діяльності: здійснення нормотворчої діяльності; здійснення інститутами громадянського суспільства делегованих державою владних повноважень; публічні консультації; громадський контроль; публічний моніторинг; вимірювання та оцінювання ефективності діяльності влади за допомогою громадян (citizen-assisted performance measurement); діяльність громадськості в правоохоронній сфері; інформаційний обмін між владою та громадськістю; адміністративно-сервісні дії держави тощо.

Як переконані більшість правників, взаємодія держави та інститутів громадянського суспільства (далі ІГС) відбувається у таких правових формах: 1) Участь ІГС у нормотворчій діяльності держави, яка забезпечується її участю у розробленні та обговоренні проектів нормативно-правових актів: громадське обговорення проектів нормативних актів; консультації з громадськістю в нормотворчому процесі; надання можливості для їх вільного доступу до інформації про діяльність органів виконавчої влади; 2) Участь ІГС у правозастосовчій діяльності держави, яка забезпечується шляхом передачі повністю повноважень державних органів, передачі частково повноважень державних органів, громадського контролю; 3) Участь ІГС у правоохоронній діяльності держави, яка забезпечується шляхом реалізації права складати протоколи про адміністративні правопорушення; участі ІГС у діяльності органів внутрішніх справ по забезпеченню охорони громадського порядку; реалізації права вживати спільно з працівниками міліції заходів із припинення адміністративних правопорушень і злочинів; участі ІГС з органами Державної прикордонної служби України в охороні державного кордону [1].

Громадськість бере участь у таких сферах публічного адміністрування: 1) нормотворчій (в тому числі у сфері видання нормативних і підзаконних актів суб'єктами публічної адміністрації як форми їх адміністративної діяльності); 2) правореалізації (коли громадськість самостійно бере участь в публічному адмініструванні; коли держава уповноважує їх на виконання визначених завдань і функцій щодо реалізації норм права в суспільство; коли держава та громадськість співпрацюють у сфері правозастовування); 3) правоохоронній (громадський контроль як спосіб впливу, спільні партнерські дії громадськості та правоохоронних органів, самостійна участь громадськості в правоохоронній діяльності).

Взаємодія громадськості та держави також існує в сфері судової гілки влади. В. Олійник вважає, що особливостями правових відносин, які виникають при взаємодії судової влади з інститутами громадянського суспільства в Україні, $\epsilon:$ 1) ті, що виникають на основі права людини на судовий захист; 2) мають вольовий характер (для виникнення правових відносин такого типу необхідна активність хоча б однієї з його сторін); 3) $\epsilon$ юридичним зв'язком суб'єктів відносин (формується на основі здійснення права людини на судовий захист, у зв'язку з чим суб'єкту права на судовий захист протистоїть відповідний юридичний обов'язок іншої сторони - суду); 4) особливий суб'єктний склад, що має на увазі широке коло суб'єктів відносин (учасниками можуть бути як судові установи і органи в особі державних службовців, так і окремі індивіди, соціальні групи, суспільство загалом, установи та організації міжнародного співтовариства, залучені в процес реалізації права людини на судовий захист); 5) забезпеченість повноважень і пов'язаних із ними юридичних обов'язків заходами державного і міжнародного примусу [8, с. 70-71].

Автора ж цікавить саме публічне адміністрування, тому прикладом взаємодії громадськості та держави в сфері судового адміністрування $€$ функціонування Громадської ради доброчесності, Громадської ради міжнародних експертів, співпраця між органами суддівського врядування та громадськими об'єднаннями з приводу незалежності суддів, оцінювання роботи судді громадськими об'єднаннями тощо.

Висновки. Взаємодія громадськості та держави в сфері публічного адміністрування в Україні $\epsilon$ досить специфічною та будується на основі міжнародних та європейських принципів участі інститутів громадянського суспільства в площині діяльності органів влади.

Сучасна взаємодія громадськості та держави в сфері публічного адміністрування в Україні повинна будуватися (що досить обґрунтовано доведено науковою спільнотою) на засадах деліберативної демократії, тобто через компетентне обговорення громадськістю діяльності публічної адміністрації та комплексну співпрацю громадськості та влади, в якій саме влада $\epsilon$ зацікавленим суб'єктом співпраці з громадськістю з метою росту компетенції інститутів громадянського суспільства та ефективного виконання поставлених перед державою завдань і функцій.

Взаємодія громадськості та держави у сфері публічного адміністрування в Україні здійснюється у різноманітних формах діяльності, серед яких найпоширенішими $є$ здійснення нормотворчої діяльності, виконання громадськістю делегованих державою владних повноважень, громадський контроль і моніторинг, оцінювання ефективності діяльності влади за допомогою громадян (citizen-assisted performance measurement), 


\section{адміністративної реформи}

діяльність громадськості в правоохоронній сфері, реалізація адміністративно-сервісних дій держави тощо.

Громадськість бере участь у різних сферах публічного адміністрування: нормотворчій (в тому числі у сфері видання нормативних і підзаконних актів суб'єктами публічної адміністрації як форми їх адміністративної діяльності); правореалізації (коли громадськість самостійно бере участь у публічному адмініструванні; коли держава уповноважує їх на виконання визначених завдань і функцій щодо реалізації норм права в суспільство; коли держава та громадськість співпрацюють у сфері правозастовування); правоохоронній (громадський контроль як спосіб впливу, спільні партнерські дії громадськості та правоохоронних органів, самостійна участь громадськості в правоохоронній діяльності); сфері судового адміністрування (функціонування Громадської ради доброчесності, Громадської ради міжнародних експертів, співпраця між органами суддівського врядування та громадськими об'єднаннями з приводу незалежності суддів, оцінювання роботи судді громадськими об'єднаннями тощо).

\section{Література}

1. Взаємодія держави та інститутів громадянського суспільства : Роз'яснення Міністерства юстиції України від 03.02.2011. Верховна Рада України: офіційний веб-сайт. 2019. URL: https://zakon.rada.gov.ua/laws/show/n0018323-11.

2. Дем'яненко 0.0. Громадський деліберативний дискурс як інструмент політичної модернізації. Грані. 2018. Т. 21, № 11. С. 101-107.

3. Козлов К.І. Політична модернізація: імплементація принципів Good Governance. Теорія та практика державного управління. 2010. № 4. С. 135-140.
4. Кухарева Г.П. Належне урядування як шлях до становлення дієвої системи публічного управління в Україні. Теорія та практика державного управління. 2015. Вип. 3. С. 76-83.

5. Медведська В.Ю. Деліберативні механізми взаємодії влади та громадянського суспільства. Молодий вчений. 2019. № 9(1). С. 18-23.

6. Мельник Н.В. Взаємодія інститутів громадянського суспільства з органами державної влади. Науковий вісник Львівського державного університету внутрішніх справ. Серія: Юридична. 2015. Вип. 3. С. 17-25.

7. Національна стратегія сприяння розвитку громадянського суспільства в Україні на 2016-2020 роки : затверджена Указом Президента України від 26 лютого 2016 року № 68/2016. Верховна Рада України: офіційний веб-сайт. 2019. URL: https: / /zakon.rada.gov.ua/laws/show/ $\mathrm{ru} / 68 / 2016$ ?lang $=\mathrm{uk}$

8. Олійник В.М. Взаємодія судової влади з інститутами громадянського суспільства в Україні: системний підхід. Журнал східноєвропейського права. 2016. № 34. C. 65-76.

9. Чепік-Трегубенко О.С. Удосконалення взаємодії органів публічної влади з інститутами громадянського суспільства. Науковий вісник Дніпропетровського державного університету внутрішніх справ. 2015. № 2. С. 120-126.

10. Шаульська Г.М. Деякі сучасні механізми взаємодії влади і громадянського суспільства в Україні: аналіз ефективності. Наукові записки Інституту законодавства Верховної Ради України. 2019. № 2. С. 180-189.

Левченко Д. С., orcid.org/0000-0001-8343-2260 аспірант

Науково-дослідного інституту публічного права 